\title{
STUDI KOMPARASI METODE IQRO' DAN METODE SEPULUH JAM BELAJAR MEMBACA ALQURAN DALAM PEMBELAJARAN BACA TULIS ALQURAN MAHASISWA
}

\author{
Yunita Furi Aristyasari 1) * \\ Chusnul Azhar ${ }^{2)}$ \\ 1,2 Universitas Muhammadiyah Yogyakarta \\ *E-mail: yunita.furi.aristyasari@umy.ac.id
}

\begin{abstract}
Reading the Qur'an properly is an obligation for a Muslim. Therefore, every Muslim need guidance in reading the Qur'an from an early age. However, reality shows that not a few adults are not able to read the Qur'an in accordance with the rules of recitation. In an effort to improve the ability to read and write al-Qur'an, the Institute for Islamic Studies and Practicing has used several methods, namely the Iqro method and the ten-hour of reading Qur'an learning method. This study aims to: first, determine the effectiveness of the Iqro and the ten-hour of reading Qur'an learning method on the reading and writing Qur'an ability of Faculty of Engineering students. Second, the difference in the influence of the two methods on the reading and writing Qur'an ability of Faculty of Engineering students. This study uses a quantitative approach with a different test technique using the Mann-Whitney test because the normality test shows abnormal data. The results showed that $\mathrm{H} 1$ was accepted, namely the Iqro method and the tenhour of reading Qur'an learning method significantly in improving the literacy skills of Faculty of Engineering students Muhammadiyah University, Yogyakarta. A comparison test between the two methods also shows that $\mathrm{H} 1$ is accepted, that is the ten-hour of reading Qur'an learning method more significantly in improving the ability of reading and writing the Qur'an.
\end{abstract}

Keywords: Iqro' method, Ten-hour of reading Qur'an learning method, reading and writing Qur'an learning

\begin{abstract}
Abstrak
Membaca Alquran dengan baik dan benar merupakan suatu kewajiban yang melekat bagi seorang muslim. Sebab itu, setiap muslim membutuhkan bimbingan membaca Alquran sejak dini. Namun, realitas menunjukkan bahwa tidak sedikit orang dewasa tidak mampu membaca Alquran sesuai dengan kaidah ilmu tajwid. Hal ini yang melatarbelakangi pembelajaran Baca Tulis Alquran di Universitas Muhammadiyah Yogyakarta. Dalam upaya meningkatkan kemampuan baca tulis Alquran, Lembaga Pengkajian dan Pengamalan Islam telah memanfaatkan beberapa metode, yaitu metode Iqro' dan metode sepuluh jam belajar membaca Alquran. Penelitian ini bertujuan untuk mengetahui efektivitas metode Iqro' dan metode sepuluh jam belajar membaca Alquran terhadap kemampuan BTA mahasiswa Fakultas Teknik dan perbedaan pengaruh antara kedua metode tersebut terhadap kemampuan BTA mahasiswa Fakultas Teknik. Penelitian ini menggunakan pendekatan kuantitatif dengan teknik uji beda menggunakan uji Mann-Whitney dikarenakan uji normalitas menunjukkan data tidak normal. Hasil penelitian menunjukkan bahwa H1 diterima, yaitu metode Iqro' dan metode sepuluh jam belajar membaca Alquran signifikan dalam meningkatkan kemampuan baca tulis Alquran mahasiswa Fakultas Teknik Universitas Muhammadiyah Yogyakarta. Uji perbandingan antara kedua metode juga menunjukkan H1 diterima, yaitu metode sepuluh jam belajar membaca Alquran lebih signifikan dalam meningkatkan kemampuan baca tulis Alquran.
\end{abstract}

Kata Kunci: Metode Iqro', Metode sepuluh jam belajar membaca Alquran, pembelajaran BTA 


\section{PENDAHULUAN}

Alquran sebagai pedoman hidup manusia menjadi suatu objek yang wajib hukumnya dipelajari bagi setiap manusia, khususnya umat Islam. Dalam upaya mempelajari dan mengamalkan Alquran, hal yang pertama diutamakan untuk dilakukan adalah membaca Alquran dengan baik dan benar sesuai kaidah tajwid. Kewajiban membaca Alquran dengan baik dan benar sesuai dengan kaidah ilmu tajwid berlaku bagi setiap muslim. Alquran bagi Persyarikatan Muhammadiyah merupakan sumber utama serta nilai utama yang menjadi pondasi sekaligus sebagai titik pusat inspirasi yang menyatu dalam seluruh denyut nadi gerakan Muhammadiyah termasuk warga dan amal usahanya (LPPI, 2017).

Universitas Muhammadiyah Yogyakarta sebagai salah satu institusi pendidikan Muhammadiyah memiliki visi pencapaian unggul dan islami. Visi unggul Universitas Muhammadiyah terletak pada pengembangan ilmu pengetahuan dan teknologi. Sementara visi islami Universitas Muhammadiyah Yogyakarta lebih ditampilkan dalam bentuk kegiatan-kegiatan terprogram yang diperuntukkan bagi semua civitas akademika, khususnya mahasiswa.

Dalam upaya mencapai visi Islami, Universitas Muhammadiyah Yogakarta sangat konsisten dalam melaksanakan program-program keislaman sejak mahasiswa terdaftar menjadi bagian dari civitas akademika kampus ini. Salah satu program keislaman kampus yang secara konsisten dijalankan adalah BTA atau Baca Tulis Alquran. Program ini diadakan setiap sore dengan waktu yang sudah terjadwal masing-masing bagi setiap program studi. Program ini dikelola oleh Lembaga Pengkajian dan Pengamalan Islam (LPPI) sebagai pusat lembaga keislaman yang berada di kampus Universitas Muhammadiyah Yogyakarta.

Metode pembelajaran Baca Tulis Alquran saat ini menggunakan metode Sepuluh Jam Belajar Membaca Alquran dilengkapi dengan modulnya sebagai media pembelajaran. Penelitian yang sudah dilakukan menunjukkan bahwa penggunaan metode ini dalam pembelajaran Alquran mampu meningkatkan kemampuan membaca Alquran bagi mahasiswa. Namun, dibalik keberhasilan penggunaan metode ini ternyata belum cukup membawa kepuasan bagi sebagian ustadz atau ustadzah pembimbing dalam membimbing bacaan Alquran bagi para mahasiswa. 
Dari penelitian pendahuluan yang peneliti lakukan, pembimbing mengakui kelebihan dari metode sepuluh jam belajar membaca Alquran. Namun, beberapa di antara pembimbing tersebut juga mengakui bahwa tidak sepenuhnya cukup jika hanya memakai modul dan metode tersebut. Sehingga, mereka tetap menggunakan metode Iqro' sebagai metode tambahan membaca Alquran. Metode Iqro' merupakan metode yang popular digunakan sampai saat ini dan dapat digunakan oleh siapapun yang bertujuan untuk mengajarkan ataupun belajar membaca Alquran. Sebelum menggunakan metode sepuluh Jam Belajar Membaca Alquran, proses pembelajaran Baca Tulis Qur'an bagi mahasiswa menggunakan metode Iqro'.

Berdasarkan kondisi di atas, peneliti bermaksud mengetahui penerapan dan efektivitas kedua metode pembelajaran Alquran tersebut dalam memberikan pengaruh terhadap peningkatan kemampuan membaca Alquran bagi mahasiswa beserta signifikansi perbandingan antara kedua metode tersebut.

\section{METODE PENELITIAN}

Penelitian ini diawali dengan menentukan populasi dan sampel penelitian. Populasi dalam penelitian ini adalah seluruh mahasiswa Universitas Muhammadiyah Yogyakarta. Dikarenakan tujuan penelitian ini tidak untuk menggeneralisasi populasi, maka penulis menggunakan teori nonprobability sampling dengan teknik purposive sampling. Peneliti mengambil subyek penelitian mahasiswa Fakultas Teknik UMY dengan asumsi bahwa rata-rata mahasiswa Teknik merupakan mahasiswa yang cukup intens mengikuti perkuliahan baca tulis Alquran. Asumsi ini didasarkan pada hasil wawancara peneliti kepada staf Lembaga Pengamalan dan Pengkajian Islam (selanjutnya disingkat LPPI). Tujuan penggunaan purposive sampling sebagai teknik pemilihan dan pengambilan sampel adalah meminimalisasi faktor-faktor luar yang mempengaruhi hasil bimbingan baca tulis Alquran, terutama berkaitan dengan masalah kehadiran dalam kegiatan bimbingan baca tulis Alquran.

Penelitian ini dibagi ke dalam beberapa tahap, yaitu: 1) melakukan uji efektivitas metode Iqro' terhadap hasil bimbingan baca tulis Alquran dengan membandingkan hasil sebelum dilakukan bimbingan dan setelah dilakukan bimbingan. Dalam pengujian ini, peneliti mengambil subyek penelitian mahasiswa Fakultas Teknik angkatan 2016 sebagai sampel penelitian. 2) melakukan uji efektivitas metode melalui penggunaan 
modul sepuluh jam belajar membaca Alquran. Dalam pengujian ini, peneliti mengambil subyek penelitian mahasiswa Fakultas Teknik angkatan 2017 sebagai sampel penelitian. 3) melakukan uji perbandingan efektivitas antara metode Iqro' dan metode menggunakan modul sepuluh jam belajar membaca Alquran terhadap hasil bimbingan baca tulis Alquran mahasiswa Fakultas Teknik Universitas Muhammadiyah Yogyakarta.

Prosedur penelitian ini secara garis besar sebagai berikut: Pertama-tama, penulis menentukan terlebih dahulu uji normalitas data yang digunakan dalam penelitian ini. Kedua, menguji hipotesis yaitu menentukan uji beda yang digunakan dengan mengetahui terlebih dahulu hasil uji normalitas sebelumnya. Ketiga, menganalisis hasil pengujian perbedaan antara kedua metode yang digunakan tersebut.

\section{Pengajuan Hipotesis}

Dalam penelitian ini, hipotesis yang diajukan terdiri dari $\mathrm{HO}$ dan $\mathrm{H} 1$ yang terbagi ke dalam tiga bagian:

a. Uji efektivitas metode Iqro' terhadap peningkatan hasil bimbingan baca tulis Alquran mahasiswa Fakultas Teknik angkatan tahun akademik 2016 Universitas Muhammadiyah Yogyakarta

H0: Penggunaan metode Iqro' tidak efektif terhadap peningkatan hasil bimbingan baca tulis Alquran mahasiswa Fakultas Teknik angkatan tahun akademik 2016 Universitas Muhammadiyah Yogyakarta

H1: Penggunaan metode Iqro' efektif terhadap peningkatan hasil bimbingan baca tulis Alquran mahasiswa Fakultas Teknik angkatan tahun akademik 2016 Universitas Muhammadiyah Yogyakarta

b. Uji efektivitas metode Iqro' terhadap hasil bimbingan baca tulis Alquran mahasiswa Fakultas Teknik angkatan tahun akademik 2017 Universitas Muhammadiyah Yogyakarta

H0: Penggunaan metode melalui modul sepuluh jam belajar membaca Alquran tidak efektif terhadap peningkatan hasil bimbingan baca tulis Alquran mahasiswa Fakultas Teknik angkatan tahun akademik 2017 Universitas Muhammadiyah Yogyakarta

H1: Penggunaan metode melalui modul sepuluh jam belajar membaca Alquran efektif terhadap peningkatan hasil bimbingan baca tulis Alquran mahasiswa 
Fakultas Teknik angkatan tahun akademik 2017 Universitas Muhammadiyah Yogyakarta

c. Uji perbandingan antara metode Iqro' dan metode melalui modul sepuluh jam belajar terhadap hasil bimbingan belajar mahasiswa Fakultas Teknik

H0: Tidak ada perbedaan yang signifikan antara hasil pencapaian baca tulis Alquran melalui metode Iqro' dan metode sepuluh jam belajar cepat.

H1: Ada perbedaan yang signifikan antara hasil pencapaian baca tulis Alquran melalui metode Iqro' dan metode sepuluh jam belajar cepat.

\section{HASIL DAN PEMBAHASAN}

\section{A. Pembelajaran Baca Tulis Alquran}

Membaca merupakan pintu gerbang masuknya berbagai macam informasi dan ilmu pengetahuan. Hal ini pun sudah diisyaratkan oleh Allah dalam wahyuNya yang turun pertama kali kepada Nabi Muhammad Saw. "Bacalah dengan (menyebut) nama Tuhanmu Yang menciptakan". Menurut para ahli, makna membaca dalam ayat tersebut memiliki makna yang luas, seperti mengamati, memperhatikan, meneliti, mengeksplorasi, menginvestigasi dan lain sebagainya. Tujuan dari semua kegiatan membaca tersebut pada akhirnya bermuara pada satu tujuan, yaitu mengenal Allah sebagai pencipta alam.

Maka, perintah dengan lafadz umum tersebut pun berimplikasi kepada objek yang dibaca. Untuk mencapai tujuan pengenalan Allah maka manusia harus membaca ayat-ayat atau tanda-tanda yang mengindikasikan keberadaan-Nya. Ayat atau tanda-tanda yang Allah berikan untuk menjadi objek bacaan secara umum terbagi menjadi dua, yakni ayat kauniyah dan ayat Qauliyah. Ayat kauniyah meliputi alam semesta yang tercipta di dunia. Sementara, ayat qauliyah adalah firman Allah yang termaktub dalam kitab suci Alquran.

Alquran sebagai ayat Qauliyah menjadi bacaan yang wajib dibaca oleh mereka yang mengaku muslim. Tidak sekedar menjadi bacaan wajib, umat muslim juga harus memahami makna-makna yang terkandung di dalamnya. Dengan pemahaman yang baik, maka fungsi Alquran sebagai petunjuk pun akan mampu terrealisasi dengan mudah. Sebagai langkah awal dalam mempelajari dan memahami Alquran, maka seyogyanya umat muslim mampu membacanya dengan 
baik dan benar. Hal ini telah disampaikan dalam sebuah hadis yang diriwayatkan oleh Mush'ab bin Sa'ad bin Abi Waqash, dari ayahnya, dia berkata: "Rasulullah saw bersabda: orang yang paling baik diantara kalian adalah orang yang mempelajari al Qur'an dan mengajarkannya".

Maka, di sinilah letak pentingnya pembelajaran Alquran melalui baca dan tulis atau yang selanjutnya disingkat dengan pembelajaran BTA. Pembelajaran merupakan sebuah proses yang meliputi belajar dan mengajar yang terpadu dalam sebuah interaksi yang dilakukan bersama-sama antara pengajar dan mereka yang belajar. Dalam suatu proses pembelajaran dibutuhkan suatu metode yang tepat sehingga sasaran dan tujuan pembelajaran dapat tercapai dengan efektif dan efisien.

Di samping landasan normatif dalam Alquran dan Sunnah, terdapat landasan yuridis yang mendasari pembelajaran Baca Tulis Alquran. Pertama, Komari dalam (Gafur, 2013) mengungkapkan bahwa keberhasilan suatu metode pembelajaran sangat ditentukan oleh beberapa hal, yaitu: 1) kemampuan guru, 2) siswa, 3) materi pembelajaran, 4) lingkungan, 5) media/alat pembelajaran dan 6) tujuan pemelajaran yang ingin dicapai. Dalam pembelajaran BTA harus menggunakan metode. Dengan menggunakan metode yang tepat, akan menjamin tercapainya tingkat keberhasilan yang lebih tinggi dan merata bagi siswa. Belajar membaca Alquran tidak hanya sekedar mempelajari huruf-huruf hijaiyyah dan harakat semata, tetapi juga bagaimana mampu membaca Alquran sesuai kaidah-kaidah tajwid.

\section{B. Metode-metode Pembelajaran BTA}

Dalam rangka mencapai keberhasilan pembelajaran Alquran sehingga mampu membaca dengan baik dan benar, beberapa ahli telah berupaya merumuskan metode yang efektif dan efisien. Ragam pembelajaran baca tulis Alquran memiliki ragam variasi. Beberapa metode yang cukup popular, antara lain adalah metode Iqra', metode al-Barqy, metode Qiro'ati, metode sima'i, metode tartil, dan metode yanbu'a. Selain metode-metode tersebut, terdapat satu metode yang baru disebut metode sepuluh jam belajar membaca Alquran. Dalam tulisan ini, penulis hanya akan memaparkan metode Iqro' dan metode sepuluh jam belajar membaca Alquran. 
1. Metode Iqro'

Metode ini dalam praktek pelaksanaannya tidak membutuhkan alat-alat yang bermacam-macam dan metode ini dapat ditekankan pada bacaan (mengeluarkan bacaan huruf atau suara huruf Alquran) dengan fasih dan benar sesuai dengan makhrojnya dan bacaannya (Anggranti, 2016). Metode ini terdiri dari enam jilid yang juga berisi petunjuk langsung yang disertai buku tajwid praktis. Jilid satu buku Iqro' dimulai dengan pengenalan huruf hijaiyyah kemudian dilanjutkan pada jilid dua yang berisi pelajaran huruf hijaiyah bersambung. Metode Iqro' secara praktis terbagi atas tiga bentuk, diantaranya (Anggranti, 2016):

a. Privat

Bentuk privat dilakukan dengan cara seorang ustadz atau pengajar memberikan pelajaran dengan jalan melatih keterampilan baca pada anak didik melalui bahan yang telah diberikan. Metode ini mirip dengan metode drill.

b. Klasikal

Bentuk klasikal dilakukan dengan cara seorang ustadz mengajar dengan membentuk satu kelas yang terdiri dari beberapa anak dan memberikan pelajaran kepada mereka dalam rangka mencapai suatu tujuan secara bersama-sama.

Mandiri

c. Bentuk mandiri dalam metode Iqro' dilakukan dengan cara seorang ustadz memberi tugas khusus kepada anak didik untuk mengerjakan sesuatu diluar jam pelajaran.

2. Metode Sepuluh Jam Belajar Cepat Membaca Alquran

Metode ini disusun dengan tujuan cepat menguasai bacaan Alquran dalam waktu singkat. Metode ini menggunakan sebuah modul Sepuluh Jam Belajar Cepat Membaca Alquran. Dengan mempelajarinya dua jam dalam sehari, maka ditargetkan kurang dari satu pekan pelajar akan dapat membaca Alquran secara baik walaupun masih harus ada perbaikan bacaan dalam segi kaidah-kaidah tajwid (LPPI, 2017). Langkah-langkah menggunakan metode belajar cepat 
membaca Alquran ini terdiri dari tujuh tahapan yang terbagi dalam 10 jam belajar sebagai berikut:

a. Jam Pertama, mengenal huruf Arab yang meliputi pelafalan huruf-huruf Arab berharakat fathah, membaca susunan huruf terpisah, dan susunan huruf bersambung.

b. Jam Kedua, melafalkan huruf-huruf Arab berharakat fathah, kasrah, dan dhammah, membaca susunan huruf Arab terpisah-pisah, membaca rangkaian huruf Arab berharakat fathah, kasrah, dhammah dan sukun.

c. Jam Ketiga, melafalkan huruf-huruf Arab berharakat fathah, kasrah, dan dhammah tanwin, membaca kata-kata berharakat fathah, kasrah, dhammah tanwin, dan sukun, membaca kata-kata menggunakan alif sukun setelah fathah, ya' sukun setelah kasrah, dan wawu sukun setelah dhammah.

d. Jam Keempat dan Kelima, membaca kata-kata menggunakan huruf qamariyah dan syamsiyah dipermulaannya yang didahului alif dan lam, membaca kata-kata menggunakan huruf berharakat fathah yang diikuti wawu sukun dan ya' sukun, serta membaca kata-kata yang bertasydid.

e. Jam Keenam dan Ketujuh, membaca rangkaian kata-kata dari Alquran yang mengandung hukum-hukum bacaan tertentu berdasarkan kaidah ilmu tajwid.

f. Jam Kedelapan dan Kesembilan, praktik membaca kutipan penggalan ayatayat Alquran.

g. Jam Kesepuluh, praktik membaca salinan surat-surat pendek dalam Alquran.

\section{Diskusi dan Temuan}

Setelah melakukan uji perbedaan atau perbandingan melalui uji MannWhitney didapatkan hasil sebagai berikut:

1. Terdapat perbedaan yang signifikan antara hasil pre-test antara kelompok mahasiswa bimbingan Iqro' (2016) dengan kelompok mahasiswa bimbingan sepuluh jam belajar membaca Alquran (2017).

2. Terdapat perbedaan yang signifikan antara hasil post-test antara kelompok mahasiswa bimbingan Iqro' (2016) dengan kelompok mahasiswa bimbingan sepuluh jam belajar membaca Alquran (2017). 
3. Perbedaan antara post-test dengan pre-test paling besar terdapat pada kelompok mahasiswa dengan bimbingan metode sepuluh jam belajar membaca Alquran (tahun akademik 2017).

Pada kenyataannya, metode sepuluh jam belajar membaca Alquran merupakan metode pembelajaran Alquran yang relatif baru dan belum banyak digunakan oleh khalayak ramai. Meskipun merupakan metode baru yang digunakan dalam pembelajaran baca tulis Alquran Universitas Muhammadiyah Yogyakarta, metode ini tampaknya cukup efektif meningkatkan hasil belajar membaca Alquran mahasiswa Fakultas Teknik, terutama bagi mahasiswa yang mendapatkan nilai rendah, seperti C, D, dan E. Mahasiswa yang mendapat nilai tersebut adalah mahasiswa yang masih belum mengenal huruf dengan baik dengan bacaanya yang masih terbata-bata. Hal ini tentu tidak lepas dari beberapa kelebihan yang dimiliki oleh metode sepuluh jam belajar membaca Alquran, seperti penulis uraikan berikut ini:

1. Materi dan metode pembelajaran bersifat bertahap, struktur dan sistematis. Sebagai contoh Sistematika pembelajaran Alquran dimulai dari huruf arab berharakat fathah, susunan huruf arab terpisah, dan huruf arab terangkai. Pembelajaran kemudian dilanjutkan dengan mengenalkan dan membaca huruf arab berharakat kasrah dan dhommah, susunan huruf arab terpisah, rangkaian huruf arab berharakat fathah, kasrah, dhammah, dan sukun.

2. Pembelajaran menggunakan metode sepuluh jam belajar membaca Alquran juga mengajarkan kepada peserta cara membaca huruf arab, rangkaian huruf arab, dan potongan ayat yang baik dan benar sesuai dengan kaidah-kaidah ilmu tajwid. Sehingga sejak awal pembelajaran, mahasiswa terbiasa membaca Alquran dengan baik dan benar. Kelebihan ini tidak dimiliki oleh metode Iqro'. Kekurangan metode Iqro' adalah bacaan-bacaan tajwid tidak dikenalkan sejak dini (Mindarningtias, 2010).

3. Tampilan dan susunan huruf arab dalam modul pembelajaran Alquran sepuluh jam belajar membaca Alquran lebih jelas dan lebih besar sehingga secara visual lebih nyaman bagi mahasiswa yang baru belajar dari dasar.

Dari kelebihan tersebut, maka metode ini memang cocok digunakan untuk pembelajaran Alquran bagi mahasiswa yang belum mencapai nilai standar 
kelulusan. Pembelajaran dengan materi yang terstruktur dan bertahap sangat membantu peserta didik supaya lebih paham terhadap materi yang diajarkan. Ibnu Khaldun menerangkan: "ketahuilah bahwa mengajar pengetahuan pada pelajar hanya efektif jika dilakukan berangsur-angsur, setapak demi setapak, dan sedikit demi sedikit" (Iqbal, 2015). Pentahapan dalam belajar tidak hanya mencakup materi, melainkan metode.

Maka, pada prinsipnya modul sepuluh jam belajar membaca Alquran telah mencakup materi dan metode yang memiliki susunan dan sistematika yang bertahap. Begitu pula dengan pembiasaan membaca contoh-contoh ayat sesuai dengan tajwid. Pengajaran tajwid lebih dini atau lebih awal tentu akan menjadikan mahasiswa terbiasa membaca contoh-contoh ayat dengan baik dan benar sehingga tidak lagi kesulitan dalam membaca ayat Alquran yang lebih utuh. (Izzan \& Saehudin, 2016).

Namun, di samping kelebihan-kelebihan yang dimiliki oleh metode dan modul sepuluh jam belajar membaca Alquran, beberapa mahasiswa juga merasa lebih nyaman memakai metode klasik, yaitu metode Iqro'. Menurut hemat penulis, metode Iqro' merupakan metode yang mampu bertahan dan tetap dipakai oleh beberapa kalangan meskipun telah muncul metode-metode baru yang dirasa oleh sebagian kalangan lebih efektif dan efisien. Apabila dibandingkan dengan metode sepuluh jam belajar membaca Alquran, metode Iqro' lebih banyak mengeksplor contoh-contoh. Pemberian banyak contoh sangat membantu dan memperkaya kemampuan mahasiswa dalam memahami teori bacaan Alquran.

Dalam mengakomodasi kebutuhan mahasiswa terhadap minat dan kenyamanan suasana belajar membaca Alquran, pembimbing tetap menggunakan Iqro' sebagai media bantu pembelajaran. Menghadirkan minat dan membangun suasana belajar yang nyaman sangat penting bagi peserta didik sebab hal tersebut dapat membangkitkan motivasi bagi peserta didik. Di sinilah pentingnya menghargai individualitas dalam proses pendidikan. Kolabarosi dan kooperasi memang hal yang penting dan patut dibangun.

Namun, kebutuhan dan minat masing-masing individu tidak bisa diabaikan. Adanya perbedaan individual menunjukkan pula adanya perbedaan kondisi belajar setiap orang, agar setiap individu dapat berkembang optimal dalam proses 
belajar diperlukan orientasi yang parallel dengan kondisi yang dimilikinya; dituntut penghargaan guru akan individualitas (Ramayulis, 2015). Apalagi mengingat bahwa tidak semua mahasiswa terbiasa dan cukup dengan pembelajaran dengan metode sepuluh jam belajar membaca Alquran. Dengan mengenali kebiasaan pola belajar dan kemampuan memahami setiap peserta didik yang beragam, maka pembimbing dapat menyesuaikan metode yang digunakan. Dalam hal ini, pembimbing dapat mengolaborasikan antara metode Iqro' dengan metode sepuluh jam belajar membaca Alquran.

Di samping kebiasaan mahasiswa menggunakan buku Iqro' sebelumnya, penggunaan buku Iqro' juga memperkaya pengalaman mahasiswa terhadap ragam-ragam contoh dari teori yang terdapat dalam metode sepuluh jam belajar membaca Alquran. Di sinilah fungsi Iqro' sebagai alat bantu peraga. Menurut Ramayulis, untuk menarik perhatian dan minat itu guru dapat menggunakan berbagai cara seperti salah satunya adalah alat peraga yang cukup (Ramayulis, 2015).

Maka pengaruh yang signifikan dari metode sepuluh jam belajar membaca Alquran terhadap kemampuan membaca a-Qur'an bagi mahasiswa Fakultas Teknik Universitas Muhammadiyah Yogyakarta (terutama bagi yag belum mencapai nilai minimum kelulusan) tidak lepas dari pertimbangan pemakaian media peraga lain, yaitu buku Iqro'.

\section{KESIMPULAN}

Secara kuantitatif, metode sepuluh jam belajar membaca Alquran dan metode Iqro' sama-sama memiliki pengaruh yang efektif dalam meningkatkan kemampuan membaca Alquran bagi mahasiswa Fakultas Teknik Universitas Muhammadiyah Yogyakarta. Namun, apabila kedua metode tersebut dibandingkan dari nilai post-test antara kedua metode, besaran signifikansi post-test dan pre-test, dan rerata, maka metode sepuluh jam belajar membaca Alquran lebih berpengaruh signifikan daripada metode Iqro'.

Metode sepuluh jam belajar membaca Alquran memiliki kelebihan sebagai berikut: Materi dan metode pembelajaran bersifat bertahap, struktur dan sistematis, pembelajaran sejak awal mengajarkan kepada peserta cara membaca huruf arab, 
rangkaian huruf arab, dan potongan ayat yang baik dan benar sesuai dengan kaidahkaidah ilmu tajwid, tampilan dan susunan huruf arab dalam modul pembelajaran Alquran sepuluh jam belajar membaca Alquran lebih jelas dan lebih besar sehingga secara visual lebih nyaman bagi mahasiswa yang baru belajar dari dasar.

Di samping memiliki kelebihan-kelebihan tersebut, pembimbing dalam menggunakan metode dan modul sepuluh jam belajar membaca Alquran tetap harus meningkatkan pembelajaran baca tulis Alquran menjadi lebih menarik dan menyenangkan sehingga dapat mendorong mahasiswa-mahasiswa lain termotivasi untuk meningkatkan kemampuan baca tulis Alquran melalui bimbingan baca tulis Alquran di Universitas Muhammadiyah Yogyakarta.

\section{DAFTAR PUSTAKA}

Anggranti, W. (2016). Penerapan Metode Pembelajaran Baca Tulis Alquran (Studi Deskriptif-Analitik di SMP Negeri 2 Tenggarong). Jurnal Intelegensia.

Fauzan, A. H. (2015). Pola Pembinaan Baca Tulis Alquran (BTQ) Sebagai Upaya Peningkatkan Kemampuan Membaca Al-Quran. Ar Risalah: Media Keislaman, Pendidikan Dan Hukum Islam, 15(1), 19-29.

Gafur, A. (2013). KAJIAN METODE PEMBELAJARAN BACA TULIS AL QUR'AN DALAM

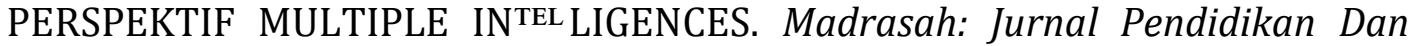
Pembelajaran Dasar, 5(1).

Hasan, S., \& Wahyuni, T. (2018). Kontribusi Penerapan Metode Qiroati Dalam Pembelajaran Membaca Alquran Secara Tartil. Al-I'tibar: Jurnal Pendidikan Islam, 5(1), 45-54.

Iqbal, A. M. (2015). Pemikiran Pendidikan Islam (Imam Ahmad Ibnu Nizar, Ed.). Yogyakarta: Pustaka Pelajar.

LPPI. (2017). Panduan Pembudayaan Tadarus Alquran. Yogyakarta: LPPI.

Pransiska, T. (2015). Fenomena Konstruktivistik dalam Metode al-Barqy dalam Pembelajaran Alquran: Perspektif Psikolinguistik. Hikmah Journal of Islamic Studies, 11(2), 31-46.

Ramayulis. (2015). Filsafat Pendidikan Islam. Jakarta: Kalam Mulia.

Siddiq, H. (2016). KEMAMPUAN BACA TULIS ALQURAN DAN MOTIVASI TADARUS ALQURAN. Al-Riwayah: Jurnal Kependidikan, 8(2), 337-353. 